\title{
Perception, Awareness and Consumer Insight Towards Purchase Intention Tanjak and Tenun Lejo Products
}

\author{
Muhammad Hamidi* \\ International Business Administration \\ Polytechnic State of Bengkalis \\ Riau, Indonesia \\ *hamidisaid74@yahoo.co.id
}

\author{
Mujiono Mujiono \\ Public Sector Accounting \\ Polytechnic State of Bengkalis \\ Riau, Indonesia. \\ mujiono@polbeng.ac.id
}

\begin{abstract}
This study aims to determine consumer perceptions, awareness level and Consumer Insight on Purchase Intention (buying interest) of the community to Tanjak and Tenun Lejo. The method in this research is quantitative research by using survey and observational method to society residing in Riau Province. Data analysis using associative techniques using SPSS version 20 program applications. The research variables are consumer perception, awareness, Consumer Insight and Purchase Intention. Data collection was done by probability sampling with Purposive sampling to 200 respondents. From this research it is known that consumer perception, Consumer Insight and Purchase Intention level to tanjak product and tenun lejo are high but awareness level is medium. Perception partially affects Purchase Intention but Awareness and Consumer Insight have no effect on purchase intention, together perceptions, awareness, consumer insight affect purchase intention.
\end{abstract}

Keywords—tenun lejo, tanjak, cunsomer

\section{INTRODUCTION}

Lejo a unique style is produced using a loom instead of a machine. The basic difference of lejo with songket cloth in general and songket Riau especially lies in the courage of the craftsmen weaving together various colors to produce a combination of weaving style that is dynamic and more varied.

In development, lejo can not only be used as a fashion, but also can be used as tanjak. Tanjak is a kind of head cover for malay men. In ancient times, tanjak was only used by certain groups and in accordance with certain conditions as well. But with the development of fashion that leads back to the local and traditional wisdom by adding a touch of modernization without leaving the authenticity of its functions and shapes, tanjak already incarnate as a complement to the Riau public dress

Lejo and tanjak is a inanimate objects, but it is a living witness of a culture, which can reveal one side of culture. Based on consumer product classification according to Kotler and Keller, Lejo and Tanjak is a specialty goods [1]. Because in the buying process consumers are willing to give a special effort and are willing to buy when having unique characteristics and different from similar products. When viewed from the aspects of use (usefulness) Lejo and Tanjak can be categorized into consumer goods and industrial goods, It is said to be consumer goods if the traditional Indonesian woven fabric has been purchased and used by the end user or consumer. It is said to be industrial goods if the traditional woven fabric is not used directly by the end user but is purchased for use or reprocessing which aims to change the value of the Indonesian traditional woven fabric from its form, nature, type, and function so that the end user gets added value or new usefulness of the traditional Indonesian woven fabric that has been developed and the future generation do not forget the philosophy contained therein.

Important indicators of a product received in the market are the high level of awareness, Consumer Insight and purchase intention consumer buying interest in the product the lack of information about awareness, Consumer Insight and consumer buying interest makes the weavers less able to predict and read and desire opportunities market. Information is only available from consumers who order products. This means that lejo and tanjak products are only requested by consumers who already know and understand the existence of lejo and tanjak only. While the ordinary people cannot predict the level of awareness to the existence of the product.

This study aims to determine perceptions, consumer awareness level of consumer insight level, consumer buying interest and the influence of consumer awareness and consumer awareness level of interest in buying weaving products lejo and tanjak.

This research basically refers to some previous research in the same domain. The most basic difference between the previous research and this research is the difference of place, time, respondent and object of research. Another difference is that this research makes awareness factor and consumer perception as a factor to assess consumer buying interest in specialty goods Tenun Lejo and Tanjak.

Research of Sasya Lestari and Menul Teguh Riyanti entitled "Study of Songket Motif Traditional Siak of Riau" [2]. This study found that Tenun Siak songket has a variety of motifs, colors and meanings that reflect the view of human life, but the development of time to make humans choose songket cloth in terms of beauty, so the philosophy contained tenun 
songket is no longer considered. The lack of love for the culture and lack of adequate information make the younger generation less interested in this songket cloth. Knowledge of the meaning of motifs and colors on songket cloth is needed so that the people of Riau Research of Bing Xu and Jianhui Chen entitled "Consumer Purchase Decision-making based on the traditional Clothing form" [3]. The results found that the key factor in purchasing consumer clothing is the decision to make the process. The results are reflected in the link between consumer behavior and the traditional clothing market, and provided guidance for fashion store managers to improve their marketing strategy.

Research of Hojjat Vahdati and Seyed Hadi Mousavi Nejad entitled "Brand Personality toward customer purchase intention: the intermediate role of electronic word of mouth and brand equity" [4]. The findings suggest that brand personality, $\mathrm{e}-\mathrm{WOM}$ and brand equity have a positive and significant influence on customer purchase intentions. The results also reveal that these factors have positive internal effects with each other. In addition, e-WOM and brand equity indicate the role of a positive mediator.

Vasista and Al Abdullatifs, entitled "Turning customer insight contributing to VMI based decision Support System in Demand Chain Management" [5]. The results of the study found that chaining strategy initiatives focused on better ways to capture demand signals closer to the source, analyzing requests to sense the most current and most accurate demand signals and shaping demand by executing and tracking promotional and pricing strategies to drive demand according to business objectives. VMI is an efficient charging practice designed to allow vendors to respond to requests without any distortion of the influence of purchasing decisions in the retail chain. This concludes by saying that there is a need to adopt innovative management methodologies such as the CRASP management methodology and the need to work on adding semantics to big data analytics based on decision support systems to enable semantic decision-making capabilities to better acquire and realize strategic business value. Sohail Younus's research, Faiza Rasheed, Anas Zia, under the title "Identifying the Factors Affecting Customer Purchase Intention" [6]. The purpose of this study was to observe the effect of independent variables (customer knowledge, buying interest, supporting celebrities and perceived value) on the dependent variable (purchase intention). The study illustrates that the relationship between the dependent variable has a significant relationship with buying interest. This is a quantitative study and the sample size of this study is 100 . The results of this study indicate that perceived value, customer knowledge, celebrity endorsement has a significant relationship with the intention of buying.

Aqeel Ahmad, Naveed Ahmad and Muhammad Nadeem entitled "The study of brand credibility and brand awareness as positive predictors for brand loyalty" [7]. This research study investigates methods of brand loyalty through brand credibility and brand awareness by applying random sampling methods and analyzed through SPSS. The findings of this study indicate that loyalty has a positive effect on association with brand credibility and also with brand awareness. This research will help managers and policymakers in designing an efficient branding strated.

\section{LITERATURE REVIEW}

Lejo is a traditional woven fabric of Malay Bengkalis, Lejo are classified in woven brocade family becouse Lejo weaving Looms woven by hand with gold and silver thread and are generally worn on formal occasions. Metallic yarn woven against a fabric brilliant effect. Lejo is a woven fabric of Songket. Songket name is derived from the word "Sungkit" which means "gouging" which there is also the process of "hooking". Both processes (gouging and hooking) are the main processes in weaving a fabric. The basic material of Songket was originally made up of silk threads and interspersed with motifs derived from gold and silver threads. But in its development Silk is hard to find and the price is expensive then the silk thread turns into a cotton tire. But the motives of the gold and silver threads are still there.

Lejo is said to grow because most people start to know weaving not just batik as one of Indonesian culture that can be used in everyday life. So in this case, there is increasing awareness of Indonesian society to weaving For the limited circle, the socialite, the upper class, the weaving is well known and used in important moments. The use of weaving is one manifestation of their self-image, but not for ordinary people.

Tanjak is a kind of headdress or traditional Malay tribal headband used by men. Tanjak can also be called by the destar, tengkolok or setanjak, this designation by cultural experts and community leaders has a different meaning depending on the type of fabric used to make headbands or headwear although the use is the same.

According to Kasturi, the terms "tengkolok", "destar", and "tanjak" are the same as those described above, the words" sticky "also refer to" cloth covering the head or sheath (rather than silk etc.) used by women, an explanation of the headache as a woman's headwear is rare until now [8].

According to Solomon et al. perception is: "The Process by which people select, organize and interpret information from outside world" [9]. According to Kotler and Keller [1], perception according to Schiffman and Kanuk, perception is: "Perception is defined as the process by which an individual," [10]. According to Kotler and Keller, every individual's perception is different from the same object because of three things: Selective Attention, Selective Distortion and Selective Retention [1].

According to Kotler and Keller Awareness is an ability to receive, feel or be aware of a particular event or object [1] Awareness or in the so-called marketing science known as brand awareness is the ability of consumers to remember a brand and that makes it different when compared with other brands. In the brand awareness is divided into four levels as the size of a consumer will be familiar to a brand. Starting from the first stage is the unaware of brand where we are completely unfamiliar and know about the brand. The second stage is brand recognition, which is the minimum level of awareness of a brand. Next is the brand recall stage then top of mind. Top of mind is the culmination of the introduction of a brand, when 
considering a product of a brand that remembers first being in a top-of-mind position and the next brand that remembers being in a brand recall position.

The definition of consumer insight according to Engel is the process of finding out more holistically about the background of the actions, thoughts and behavior of a consumer related to product and communication [11]. Analysis of statistical data is obviously very useful, but it is only up to a point only. In more complex market conditions, where many factors that cause the occurrence of something cannot be quantified simply by causal models (causation); qualitative knowledge of a deeper market is beginning to be perceived as a necessity. This is in line with the view that marketing is a combination of science and art. Consumer Insights is a major part of the art! In essence, think creatively and broader than translating data quantitatively. Dig out something that does not appear on the surface. Noteworthy about Consumer Insights: Insights does not have to come from the brand manager alone, but rather from everyone who belongs to the organization, including the owner of the company. Consumer insights need to be cultivated within the company. The existence of the position of consumer insights manager in the organization is one way to collect all relevant insights and channeled in accordance with its capacity. Insights are useless if not actionable. The challenge is how to make information unearthed as insights, become clear and understandable by the marketing team (including product development and research agency), and then translated into a real plan.

The intention to buy is a kind of decision that studies why customers buy a brand. Considering something buying a brand and planning to buy the brand helps consumers to judge how much interest it is in purchasing the product [9]. Porter also outlines the customer's intention to buy a brand that is focused not only on the same brand but also by his attitude towards other brands in the alternative choices that have been considered. Solomon explains for loyal customers whose purchasing decisions are price-sensitive and loyal to the product suggests positive recommendations to companies and even invests money in brands that show they have the extreme trust in the brand [9]. Purchasing behavior also depends on the level of competition in the industry.

According to Engel, Purchase intention is related to the 2 (two) categories of the first category of purchase intention to the product and the brand or so-called fully planned purchase [11], then the second category of purchase intention to the product category or so-called planned purchase even though the choice of brand is made at the time of purchase (point of sales). Purchase Intention is "process used to evaluate consumer decision making". Solomon defines Purchase Intention as "based on consumer attitude toward buying a brand" [9]. Meanwhile, according to Kotler definition of Purchase Intention is "consumer behavior occurs when consumer stimulated by external factors and come to purchase decision based their personal characteristics and decision making process".

\section{RESEARCH METHODOLOGY}

Before you begin to format your paper, first write and save the content as a separate text file. Complete all content and The research location is in Riau Province. Data source used is primary data. Technique of collecting data is done by using survey and observasional. The research population is all Riau people who like or have ever bought or own tenun lejo and tanjak. This research uses sampling design with probability sampling with purposive random sampling as many as 100 people [12]. Measuring the influence of consumer perceptions and awareness on buying interest using linear and multiple regression analysis. To assess respondents' perceptions, the methods used through the assessment of the range of values where the range of $1-1.75$ is rated low, 1.76-3.51 are rated moderate and 3.52-4 are rated high [13]. Significant role is seen from the volue of $t_{\text {count }}>t_{\text {table }}$ on $\alpha=0.05$ two side with a value $\mathrm{p}<0.05$. While the stimultaneous hypotesis is acceptable or proven when three variable produce $\mathrm{F}$ count $>\mathrm{F}$ table on $\alpha=$ 0.05 two side with a value $\mathrm{p}<0.05$.

\section{RESULTS AND DISCUSSION}

\section{A. Value of Perseption Level}

Perception is the experience of the event object or the relationships obtained by concluding information and interpreting the message. A person who has been motivated for the attitude to act and the actions performed by a person is influenced by perception. To see how the people's perception of Riau Lejo and Tanjak, can be seen in the following table:

TABLE I. VALUE OF PERCEPTION LEVEL

\begin{tabular}{|c|c|c|c|c|c|c|c|}
\hline \multirow[t]{2}{*}{ No } & \multirow[t]{2}{*}{ Indicator } & 4 & 3 & 2 & 1 & \multirow[t]{2}{*}{ Average } & \multirow[t]{2}{*}{ Eplanation } \\
\hline & & ${ }^{a} \boldsymbol{V H}$ & ${ }^{b} \boldsymbol{H}$ & ${ }^{{ }^{c} L}$ & ${ }^{d} V L$ & & \\
\hline \multirow[t]{2}{*}{1} & \multirow{2}{*}{$\begin{array}{l}\text { Perseption } \\
1\end{array}$} & 76 & 24 & 0 & 0 & \multirow[t]{2}{*}{3.76} & \multirow[t]{2}{*}{ High } \\
\hline & & $76 \%$ & $24 \%$ & 0 & 0 & & \\
\hline \multirow[t]{2}{*}{2} & \multirow{2}{*}{$\begin{array}{l}\text { Perseption } \\
2\end{array}$} & 73 & 24 & 3 & 0 & \multirow[t]{2}{*}{3.70} & \multirow[t]{2}{*}{ High } \\
\hline & & $73 \%$ & $24 \%$ & $3 \%$ & 0 & & \\
\hline \multirow[t]{2}{*}{3} & \multirow{2}{*}{$\begin{array}{l}\text { Perseption } \\
3\end{array}$} & 76 & 24 & 0 & 0 & \multirow[t]{2}{*}{3.76} & \multirow[t]{2}{*}{ High } \\
\hline & & $76 \%$ & $24 \%$ & 0 & 0 & & \\
\hline \multicolumn{6}{|c|}{ Average } & 3.74 & High \\
\hline
\end{tabular}

From table data it is known that respondents' perceptions of lejo and tanjak are on average at 3.74 and are considered high, indicating that the community provides a good response to the revelation on this indicator. Further explained that the people of Riau already know and understand the existence of Lejo and Tanjak, the people of Riau get the information or knowledge is clear, have a high stimulation to use and always remember to reuse lejo and tanjak.

\section{B. Value of Awarness Level}

Brand Awareness is the ability of a potential buyer to recognize or recall that a brand is part of a particular product category. Therefore, brand awareness of a brand or product has a very important meaning for the producer (brand owner), 
because most consumers will tend to buy products that are known or remembered by them. The following is the response

TABLE II. VALUE OF AWARENESS LEVEL

\begin{tabular}{|l|l|l|l|l|l|l|l|}
\hline No & Indicator & $\mathbf{4}$ & $\mathbf{3}$ & $\mathbf{2}$ & $\mathbf{1}$ & Average & Eplanation \\
\cline { 3 - 6 } & & ${ }^{a} \boldsymbol{V} \boldsymbol{H}$ & ${ }^{\boldsymbol{b}} \boldsymbol{H}$ & ${ }^{\boldsymbol{C}} \boldsymbol{L}$ & ${ }^{d} \boldsymbol{V} \boldsymbol{L}$ & & \\
\hline 1 & Awarness & 0 & 91 & 6 & 3 & 2.81 & Medium \\
\cline { 3 - 6 } & 0 & $91 \%$ & $6 \%$ & $3 \%$ & & \\
\hline 2 & Awarness & 0 & 96 & 4 & 0 & 2.98 & Medium \\
\cline { 3 - 6 } & 2 & 0 & $96 \%$ & $4 \%$ & 0 & & \\
\hline \multirow{2}{*}{3} & Awarness & 0 & 95 & 5 & 0 & 2.92 & Medium \\
\cline { 2 - 5 } & 3 & 0 & $95 \%$ & $5 \%$ & 0 & & \\
\hline \multirow{2}{*}{4} & $\begin{array}{l}\text { Awarness } \\
4\end{array}$ & 0 & 96 & 3 & 1 & 2.94 & Medium \\
\cline { 2 - 5 } & 0 & $96 \%$ & $3 \%$ & $1 \%$ & & \\
\hline \multicolumn{7}{|c|}{ Average } \\
\hline
\end{tabular}

a. Very high

${ }^{\text {b. }}$ High

c. Low

d. Very Low

The results of the above data processing, explains that the average awareness of the people of Riau to lejo and tanjak is at 2.91 and rated moderate or medium. This explains that the people of Riau have not fully awareness of lejo and tanjak, Riau people have clear knowledge and information but not deeper yet, it is known that people have not known much about the form or variety of lejo and tanjak, consequently public awareness to buy and show satisfaction towards lejo and tanjak is not high or categorized moderate.

\section{Value of Consumer Insight Level}

Assessment of respondents to consumer insight can be seen in the following table 3 :

TABLE III. VALUE OF CONSUMER INSIGHT LEVEL

\begin{tabular}{|c|c|c|c|c|c|c|c|}
\hline \multirow[t]{2}{*}{ No } & \multirow[t]{2}{*}{ Indicator } & 4 & 3 & 2 & 1 & \multirow[t]{2}{*}{ Average } & \multirow[t]{2}{*}{ Eplanation } \\
\hline & & ${ }^{a} \boldsymbol{V H}$ & ${ }^{b} \boldsymbol{H}$ & ${ }^{c} L$ & ${ }^{d} V L$ & & \\
\hline \multirow[t]{2}{*}{1} & \multirow{2}{*}{$\begin{array}{l}\text { Consumer } \\
1\end{array}$} & 86 & 11 & 3 & 0 & \multirow[t]{2}{*}{3.83} & \multirow[t]{2}{*}{ High } \\
\hline & & $86 \%$ & $11 \%$ & $3 \%$ & 0 & & \\
\hline \multirow[t]{2}{*}{2} & \multirow{2}{*}{$\begin{array}{l}\text { Consumer } \\
2\end{array}$} & 85 & 11 & 4 & 0 & \multirow[t]{2}{*}{3.81} & \multirow[t]{2}{*}{ High } \\
\hline & & $85 \%$ & $11 \%$ & $4 \%$ & 0 & & \\
\hline \multirow[t]{2}{*}{3} & \multirow{2}{*}{$\begin{array}{l}\text { Consumer } \\
3\end{array}$} & 84 & 11 & 5 & 0 & \multirow[t]{2}{*}{3.79} & \multirow[t]{2}{*}{ High } \\
\hline & & $84 \%$ & $11 \%$ & $5 \%$ & 0 & & \\
\hline \multicolumn{6}{|c|}{ Average } & 3.81 & High \\
\hline
\end{tabular}

The respondent's response to Consumer Insight average is at 3.81 and is considered high, it indicates that the people of Riau although not yet have a good knowledge of lejo and tanjak, but they give a good response to the craftsmen or makers tenun lejo and Tanjak, this is due to artisans or makers lejo and tanjak make sales and provide knowledge to the buyer so as to provide stimulation to the buyer to seek and understand lejo and tanjak more deeply and fully support to makers lejo and tanjak to conduct research and development of the product which has been made.

\section{Partial and Simultaneous Test}

Partial test (T test) is done to know how influence between perception, Awarness, Custumer Insight to Purchase Intention. To determine using Hypothesis are: [7] Ho, where partially of the people of Riau to awareness of lejo and tanjak products.

Perception, Awarness and Custumer Insight have no influence with Purchase Intention and [3] Ha, where partially Perception, Awarness and Custumer Insight have influence with Purchase Intention. For tcount value is done by two side test that is $\mathrm{dk}=$ $\mathrm{n}-3$ and $\mathrm{dk}=100-3=97$, with error level is set at $0,05(5 \%)$ hence ttable $=1,984$. Ho, will apply if tcount $<$ ttable, while Ha applies if tcount $>$ ttable.

For Perception of partial test result ( $t$ test) shows that consumer perception on purchasing decision is shown with tcount value 4,641 , with its significance value equal to 0,000 $<\alpha=0,05$. The value of ttable is 1.984 , tcount is bigger than ttable $(4,641>1,984)$, Ho is accepted and it shows that perception has influence and positive value to purchasing decision.

Awarness, from partial test results (t test) indicates that awarness to purchase decision is shown with tcount value of 1.3991 with its significance value of $0.000<\alpha=0,05$. The ttable value is 1,984 , if $\mathrm{t}$ is smaller than ttable $(-1,3991$ $<1,984)$, Ha is accepted and it indicates that awarness has no effect and negative value to purchase decision.

\section{CONCLUSION}

- The level of consumer perception of the lejo and tanjak products is high, this means that the people of Riau know and understand the existence of lejo and tanjak, the people of Riau get clear information or knowledge, have a high stimulation to use and always remember to reuse lejo and tanjak.

- The level of consumer awareness of lejo and tanjak products is moderate. This explains that the people of Riau have not fully awareness of lejo and tanjak, Riau people have clear knowledge and information but not yet deeply, it is known that the community has not much knowledge form or various Lejo and Tanjak Leather, as a result the public awareness to buy and show satisfaction towards lejo and tanjak is not high or categorized being.

- The level of Purchase Intention to the lejo and tanjak products is high. This fact indicates that Riau people's desire to buy and own lejo and tanjak is high. This is due to the support and necessity of local government to the people in Riau to always use songket fabrics including lejo and tanjak on every moment.

- Partially perceptions of consumers have a positive and positive impact on purchasing decisions, but awareness and purchase intention has no influence and negative value to the purchase decision. From simultaneous test results, perception, awareness, customer insight together affect purchase intention lejo and tanjak product.

\section{REFERENCES}

[1] P. Kotler and K.L. Keller, Manajemen pemasaran, 2009. 
[2] S. Lestari and M.T. Riyanti, "Kajian Motif Tenun Songket Melayu Siak Tradisional Khas Riau," Jurnal Dimensi DKV Seni Rupa dan Desain, vol. 2, no, 1, pp. 33-48, 2017.

[3] B. Xu and J. Chen, "Consumer Purchase Decision-Making Process Based on the Traditional Clothing Shopping Form," J Fashion Technol Textile Eng 5: 3. of, vol. 12, no. 2, 2017

[4] H. Vahdati and S.H. Mousavi Nejad, "BRAND PERSONALITY TOWARD CUSTOMER PURCHASE INTENTION: THE INTERMEDIATE ROLE OF ELECTRONIC WORD-OF-MOUTH AND BRAND EQUITY," Asian Academy of Management Journal, vol. 21 , no $.2,2016$

[5] T.G.K. Vasista and A.M. AlAbdullatif, "Turning customer insights contributing to VMI based decision support system in demand Chain management," International Journal of Managing Value and Supply Chains, vol. 6, no. 2, pp. 37-45, 2015

[6] S. Younus, F. Rasheed, and A. Zia, "Identifying the factors affecting customer purchase intention," Global Journal of Management and Business Research,2015.
[7] A. Ahmad, N. Ahmad and M. Nadeem, "The study of brand credibility and brand awareness as positive predictors for brand loyalty," Nigerian Chapter of Arabian Journal of Busines and Management Review, vol. 62, no. 1890, pp. 1-7, 2014.

[8] G. Kasturi, Stanjak, Tanjak, Tengkolok and Destar. Malaysian Culture and Language Council, 2010.

[9] R.M. Solomon, Consumer Behavior, 8th ed, NJ, Prentice Hall, 2008.

[10] L.G. Schiffman, L.L. Kanuk and J. Wisenblit, Consumer Behavior. Upper Saddle River. J: Prentice Hall, 2000.

[11] F.J. Engel, Consumer Behaviour. 10 th edition. Harcourt, Orlando, 2012.

[12] U. Sekaran, Research Methods for Business, 5th ed. Jilid II. Third Avenue, NY: John Wiley \& Sons, Inc, 2010.

[13] P.D. Sugiyono, Metode penelitian pendidikan. Pendekatan Kuantitatif, 2010 . 